\title{
Sporosarcina newyorkensis sp. nov. from clinical specimens and raw cow's milk
}

\author{
William J. Wolfgang, ${ }^{1,2}$ An Coorevits, ${ }^{3,4}$ Jocelyn A. Cole, ${ }^{1}$ Paul De Vos, ${ }^{4}$ \\ Michelle C. Dickinson, ${ }^{1}$ George E. Hannett, ${ }^{1}$ Reashma Jose, ${ }^{5}$ \\ Elizabeth J. Nazarian, ${ }^{1}$ Peter Schumann, ${ }^{6}$ Anita Van Landschoot, ${ }^{3,4}$ \\ Samantha E. Wirth ${ }^{1}$ and Kimberlee A. Musser ${ }^{1,2}$
}

\section{Correspondence William J. Wolfgang wwolfgan@wadsworth.org}

\author{
${ }^{1}$ Wadsworth Center, Bacteriology Laboratory, New York State Department of Health, \\ PO Box 22002, Albany, NY 12201, USA \\ ${ }^{2}$ Department of Biomedical Sciences, State University of New York, Albany, NY 12201, USA \\ ${ }^{3}$ Department of Applied Engineering Sciences, Laboratory of Biochemistry and Brewing, \\ University College Ghent, Schoonmeersstraat 52, 9000 Ghent, Belgium \\ ${ }^{4}$ Laboratory of Microbiology (LM-UGent), Department of Biochemistry and Microbiology, \\ Ghent University, K.L. Ledeganckstraat 35, 9000 Ghent, Belgium \\ ${ }^{5}$ Department of Biomedical Technology, Albany College of Pharmacy, 106 New Scotland Ave, \\ Albany, NY 12208, USA \\ ${ }^{6}$ DSMZ-Deutsche Sammlung von Mikroorganismen und Zellkulturen GmbH, Inhoffenstraße 7B, \\ 38124 Braunschweig, Germany
}

In August 2008, the Wadsworth Center Bacteriology Laboratory, New York, USA, received an isolate from

Abbreviation: CFA, cellular fatty acid.

The GenBank/EMBL/DDBJ accession numbers for the partial $16 \mathrm{~S}$ and $23 S$ rRNA gene sequences of strain $6062^{\top}$ are GU994085 and GU994086, respectively. The accession numbers for the partial 235 rRNA gene sequences of Sporosarcina ureae DSM $2281^{\top}$, S. koreensis DSM $16921^{\top}$, S. soli DSM $16920^{\top}$, S. aquimarina DSM $14554^{\top}, S$. contaminans CCUG $53915^{\top}$ and S. thermotolerans CCUG 53480 are HM245314-HM245319, respectively. Additional accession numbers are given in Table 1.

Four supplementary tables and a supplementary figure are available with the online version of this paper. human blood that was most closely related to Sporosarcina koreensis with a $16 \mathrm{~S}$ rRNA gene sequence similarity of 97.13\% (EzTaxon, Chun et al., 2007). The laboratory subsequently received ten additional isolates, all from different patients residing in New York State, having $100 \%$ 16S rRNA gene sequence similarity to the first strain (strain list, GenBank accession numbers and stock centre accession numbers are listed in Table 1). In addition, strain R-31323 was acquired, which has $100 \% 16 \mathrm{~S}$ rRNA gene sequence similarity to the New York strains, and was isolated from cow's milk in Belgium (Coorevits et al., 2008). Based on the polyphasic study below, we report the identification of twelve strains of a novel species of Sporosarcina isolated from human clinical samples and cow's milk. 
Table 1. Strain information for Sporosarcina newyorkensis sp. nov.

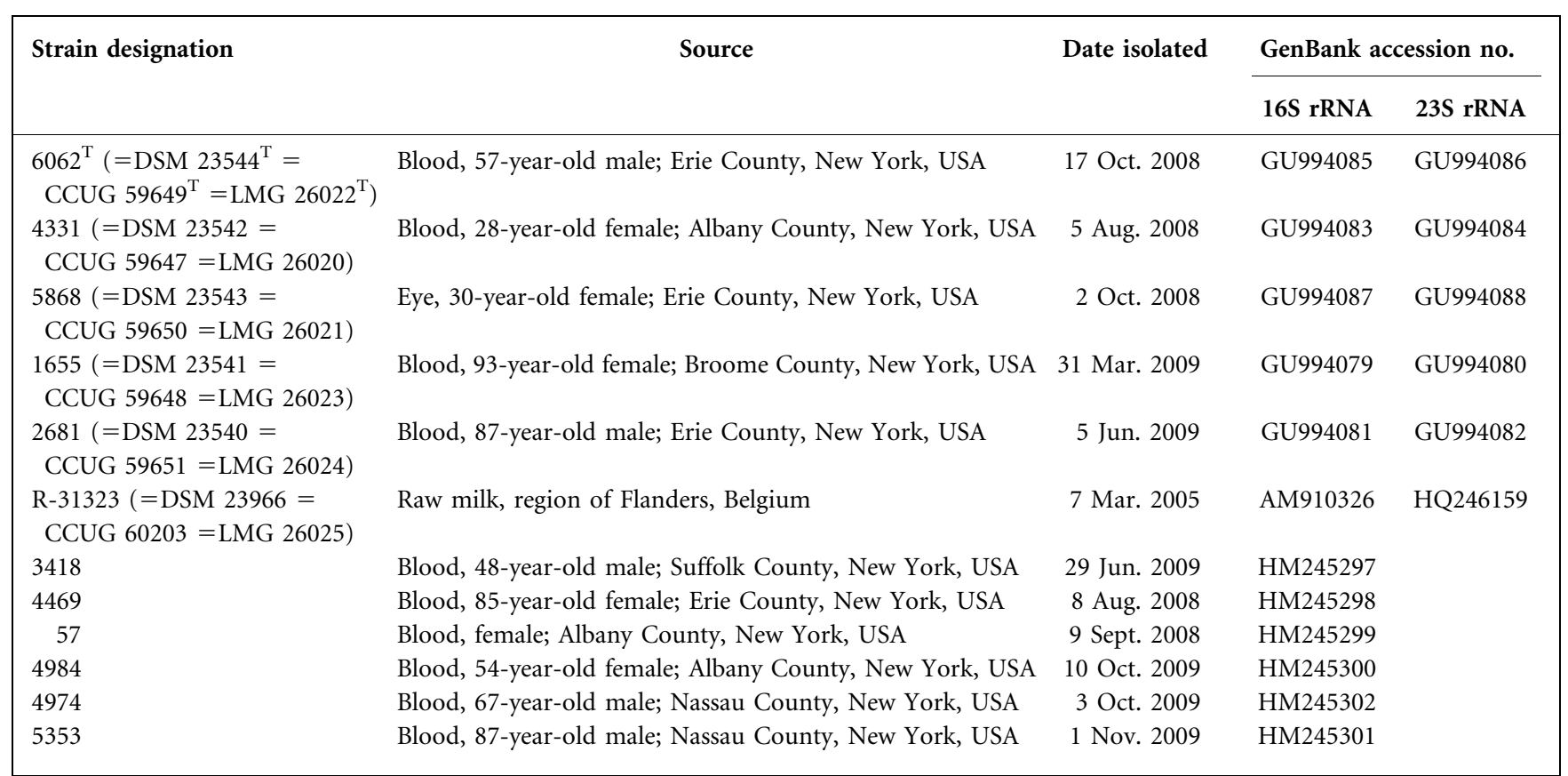

Ten of the twelve strains were isolated from human blood, one from a human eye, and one from cow's milk (Table 1). All were cultured at $37{ }^{\circ} \mathrm{C}$ on trypticase soy agar (TSA) plates (Becton Dickinson) supplemented with $5 \%$ sheep blood. For cellular fatty acid (CFA) studies, strains were grown at $28{ }^{\circ} \mathrm{C}$ on trypticase soy broth agar plates without sheep blood (TSBA). Strain $6062^{\mathrm{T}}$ was selected as the type strain and, along with five additional strains, was deposited at the DSMZ, CCUG and BCCM/LMG stock centres (Table 1).

The near full-length sequence of the 16S rRNA gene (1445-1474 nt) for eight of the isolates was determined as previously described (Wolfgang et al., 2011) with the addition of one sequencing primer $\mathrm{pF} 55^{\prime}$-GAGGAAGGTGGGGATGACGT-3' (corresponding to Escherichia coli positions 1175-1194). For strain R-31323, 16S rRNA gene sequence (1514 nt) was determined as previously described (Coorevits et al., 2008). For the three remaining isolates, the 16S rRNA gene sequence lengths ranged from 435-473 nt and were amplified and sequenced with primers 16S1 and rpD (Wolfgang et al., 2011). Each sequence contained from one to nine polymorphic sites, which were denoted using the IUPAC code. An alignment of all the sequences revealed that polymorphic sites were often conserved. However, when a strain contained a single nucleotide at a polymorphic site, that nucleotide was always concordant with one of the polymorphic residues. Therefore, these sites were considered to be matches. Using these criteria, all sequences had $100 \%$ similarity (for GenBank accession numbers refer to Table 1 ).

The identification of closely related species was carried out by using the BLAST (Altschul et al., 1997) and megaBLAST (Zhang et al., 2000) programs to compare near full-length $16 \mathrm{~S}$ rRNA gene sequences $(1474 \mathrm{nt})$ of strain $6062^{\mathrm{T}}$ against the database of $16 \mathrm{~S}$ rRNA gene sequences for type strains with validly published prokaryotic names (Chun et al., 2007). The 50 sequences with the highest scores were then selected for the calculation of pairwise sequence similarity using a global alignment algorithm, which was implemented at the EzTaxon server (http://www.eztaxon.org/; Chun et al., 2007). Previous studies indicate that for organisms with greater than $97.0 \% 16 \mathrm{~S}$ rRNA gene sequence similarity, alternative methods must be employed, such as DNA-DNA hybridization, for determining inclusion or exclusion of the organism in closely related species (discussed in Tindall et al., 2010). Therefore, type strains for all organisms with greater than $97.0 \%$ similarity to strain $6062^{\mathrm{T}}$ (these ranged between $97.07 \%$ and $97.13 \%$ over 1454 to $1465 \mathrm{nt}$ ) were acquired to include in the polyphasic analysis. The closest species with validly published names were: Sporosarcina koreensis (F73 ${ }^{\mathrm{T}}$, DQ073393) (Kwon et al., 2007) (DSM $16921^{\mathrm{T}}$ acquired for this study), Sporosarcina contaminans (CCUG 53915 ${ }^{\mathrm{T}}$, FN298444) (Kämpfer et al., 2010), Sporosarcina ureae (DSM 2281 ${ }^{\mathrm{T}}$, AF202057) (Claus \& Fahmy, 1986) and Sporosarcina aquimarina (SW28 ${ }^{\mathrm{T}}$, AF202056) (Yoon et al., 2001) (DSM $14554^{\mathrm{T}}$ acquired for this study). Also included in some of the analyses are the type strains of Sporosarcina thermotolerans (CCUG 53480 ${ }^{\mathrm{T}}$, FN298445) (Kämpfer et al., 2010), Sporosarcina soli (I80 ${ }^{\mathrm{T}}$, DQ073394) (Kwon et al., 2007) (DSM $16920^{\mathrm{T}}$ acquired for this study) and Sporosarcina luteola (Y1 $\left.{ }^{\mathrm{T}}, \mathrm{AB} 473560\right)$ (Tominaga et al., 2009) (DSM $23150^{\mathrm{T}}$ acquired for this study), as they match just below the $97.0 \%$ level of sequence similarity.

In order to support the proposed novel species designation, DNA-DNA hybridization was performed by the DSMZ Identification Service (Braunschweig, Germany) and by us between strain $6062^{\mathrm{T}}$ and the type strains with a $16 \mathrm{~S}$ rRNA 
gene sequence similarity greater than $97.0 \%$ (Tindall et al., 2010). Spectroscopic DNA-DNA hybridization was performed in duplicate on DNA that was isolated using a French pressure cell (Thermo Spectronic) and was purified by chromatography on hydroxyapatite (Cashion et al., 1977). DNA-DNA hybridization was carried out as described by De Ley et al. (1970) under consideration of the modifications described by Huß et al. (1983) using a model Cary 100 Bio UV/VIS-spectrophotometer equipped with a Peltier-thermostatted $6 \times 6$ multicell changer and a temperature controller with in-situ temperature probe (Varian). For comparisons to strain R-31323, DNA was purified as described by Logan et al. (2000) and hybridization was performed using a modification of the microplate method described by Ezaki et al. (1989), as described by Willems et al. (2001). Hybridization values for strain $6062^{\mathrm{T}}$ against strain 4331, strain R-31323, S. koreensis DSM $16921^{\mathrm{T}}$, S. ureae DSM $2281^{\mathrm{T}}$, S. aquimarina DSM $14554^{\mathrm{T}}$, S. soli DSM $16920^{\mathrm{T}}$ and S. contaminans CCUG $53915^{\mathrm{T}}$ are shown in Supplementary Table S1 (available in IJSEM Online). Based on a cut-off of $70.0 \%$ hybridization for defining species (Wayne et al., 1987), strain $6062^{\mathrm{T}}$ belongs to the same species as strains 4331 and R-31323 and furthermore does not belong to any of the other species tested.

To obtain further support for the new species designation, we partially sequenced the $23 \mathrm{~S}$ rRNA gene for the six isolates deposited at CCUG, DSMZ and BCCM/LMG and six of the most closely related species. Amplification and sequencing were performed as previously described (Wolfgang et al., 2011) except that sequencing primer $1602 \mathrm{~F}$ was replaced with $1602 \mathrm{~F}^{\prime}$ (5'-TACCGCAAACCGACACAGGTA-3'). The $23 \mathrm{~S}$ rRNA gene sequences for the six novel strains, $6062^{\mathrm{T}}$ (GU994086), 4331 (GU994084), 5868 (GU994088), 1655 (GU994080), 2681 (GU994082), and R-31323 (HQ246159) harboured two to thirteen polymorphisms. Using the criteria established for $16 \mathrm{~S}$ rRNA polymorphisms, all polymorphic sites were matches and all six sequences were identical over 2139 nt. By contrast, for the most closely related species, S. koreensis (HM245315), S. ureae (HM245314), S. aquimarina (HM245317), S. soli (HM245316), S. contaminans (HM245318), and S. thermotolerans (HM245319), the 23S rRNA gene sequence similarity ranged from $94.65 \%$ to $97.97 \%$ over 2142 to 2147 nt (see Supplementary Table S2). Thus, $23 \mathrm{~S}$ rRNA gene sequence analysis provides additional support that the six deposited strains analysed are members of the same species.

CFA analysis was performed on a loop-full of growth from isolates cultured for $24-48 \mathrm{~h}$ at $28{ }^{\circ} \mathrm{C}$ in air, on TSBA plates. Fatty acid methyl esters were extracted using the Sherlock Microbial Identification System version 4.5 according to the manufacturer's instructions (MIDI) and were identified using an Agilent Technologies $6890 \mathrm{~N}$ gas chromatograph and method TSBA 50. For the twelve novel strains, the predominant fatty acids were iso- $\mathrm{C}_{14: 0}$, iso- $\mathrm{C}_{15: 0}$ and anteiso- $\mathrm{C}_{15: 0}$ (Supplementary Table S3). This is consistent with other species of the genus Sporosarcina; however, the relative proportions were significantly different (Table 2). Notably, the novel Sporosarcina strains generally have higher levels of iso- $\mathrm{C}_{14: 0}$ and lower levels of anteiso- $\mathrm{C}_{15: 0}$. For the closely related genera Paenisporosarcina and Psychrobacillus, some but not all of the predominant CFAs are the same (Krishnamurthi et al., 2009, 2010).

Polar lipids of S. ureae LMG $17366^{\mathrm{T}}$ and S. newyorkensis sp. nov. strains $6062^{\mathrm{T}}, 4331$ and R-31323 were extracted after aerobic growth on TSA (Oxoid) for $24 \mathrm{~h}$ at $28{ }^{\circ} \mathrm{C}$. The lipid fraction was subsequently separated by two-dimensional thin-layer chromatography according to Tindall (1990a, b). The total lipid profiles were visualized by spraying with molybdatophosphoric acid and further characterized by spraying with ninhydrin (specific for amino groups), molybdenum blue (specific for phosphates) and $\alpha$-naphthol (specific for sugars). For the S. ureae and S. newyorkensis strains examined, the polar lipid profiles were identical, with diphosphatidylglycerol, phosphatidylglycerol and phosphatidylethanolamine as the major polar lipids, along with minor amounts of two phospholipids (Supplementary Figure S1a, b). Furthermore, this profile is in agreement with other polar lipid profiles described for S. contaminans and S. thermotolerans (Kämpfer et al., 2010). The closely related genera, Paenisporosarcina and Psychrobacillus have lipid profiles that overlap with those of the novel strains (Krishnamurthi et al., 2009, 2010).

Isoprenoid quinones were extracted from lyophilized cells of strains $6062^{\mathrm{T}}$ (cultivated for one day at $37^{\circ} \mathrm{C}$ in medium 220, http://www.dsmz.de) and R-31323 (cultivated for one day at $37{ }^{\circ} \mathrm{C}$ in tryptone soy agar, Oxoid) and analysed by HPLC (Groth et al., 1996). The major menaquinone of both strains was MK-7 (>90\%) with MK-6 (approx. 2\%) found as a minor component. Additionally strain R-31323 contained MK-8 (approx. 1\%). The occurrence of MK-7 as a major menaquinone is a characteristic feature of members of the genus Sporosarcina (Yoon et al., 2001).

Peptidoglycan preparations of strains $6062^{\mathrm{T}}$ and R-31323 were purified according to the method of Schleifer (1985) after disruption of cells by shaking with glass beads and subsequent trypsin digestion. The amino acids and peptides in cell wall hydrolysates were analysed by two-dimensional ascending thin-layer chromatography (2D-TLC) on cellulose plates using previously described methods and solvent systems (Schleifer, 1985). Amino acid enantiomers were determined from the mobilities of the diastereomeric dipeptides on 2D-TLC plates analogously to data reported for paper chromatography by Schleifer (1985). The aminoterminal amino acid of the interpeptide bridge was detected by dinitrophenylation (Schleifer, 1985). The molar ratios of amino acids were determined by gas chromatography (GC $14 \mathrm{~A}$, Shimadzu) and gas chromatography-mass spectrometry (320 Singlequad, Varian) of $N$-heptafluorobutyryl amino acid isobutyl esters (Groth et al., 1996; MacKenzie, 1987). The hydrolysates $\left(4 \mathrm{M} \mathrm{HCl}, 100{ }^{\circ} \mathrm{C}, 16 \mathrm{~h}\right)$ of the peptidoglycan preparations of both strains contained lysine, alanine, glycine and glutamic acid in a molar ratio of 
Table 2. Per cent fatty acid composition of strain $6062^{\top}$ and closely related taxa

Taxa: 1 , strain $6062^{\mathrm{T}}$; 2, S. ureae DSM $2281^{\mathrm{T}}$; 3, S. aquimarina DSM $14554^{\mathrm{T}} ; 4$, S. soli DSM $16920^{\mathrm{T}}$; 5 , S. koreensis DSM $16921^{\mathrm{T}}$; 6 , S. thermotolerans CCUG $53480^{\mathrm{T}} ; 7$, S. contaminans CCUG $53915^{\mathrm{T}} ; 8$, S. luteola DSM $23150^{\mathrm{T}}$; 9, S. antarctica N- $05^{\mathrm{T}} ; 10$, S. globispora DSM $4^{\mathrm{T}} ; 11$, S. psychrophila KCTC $3446^{\mathrm{T}}$; 12, S. pasteurii KCTC $3558^{\mathrm{T}}$; 13 , S. saromensis $\mathrm{HG} 645^{\mathrm{T}}$. Fatty acid methyl esters for which no values were greater than $0.1 \%$ for any organism have been omitted from the table. The three most prevalent fatty acids for each isolate are in bold text.

\begin{tabular}{|c|c|c|c|c|c|c|c|c|c|c|c|c|c|}
\hline Fatty acid & 1 & 2 & 3 & 4 & 5 & 6 & 7 & 8 & $9^{a_{\star}}$ & $10^{b}$ & $11^{b}$ & $12^{b}$ & $13^{c}$ \\
\hline \multicolumn{14}{|l|}{ Saturated } \\
\hline $\mathrm{C}_{14: 0}$ & 0.6 & 0.3 & 2.4 & 2.5 & 0.5 & 9.0 & 0.4 & 1.2 & - & 0.6 & 0.9 & 1.1 & - \\
\hline $\mathrm{C}_{16: 0}$ & 0.8 & 0.6 & 3.0 & 2.2 & 0.2 & 10.6 & 0.5 & 0.5 & 1.2 & 0.9 & 1.5 & 4.7 & 1.4 \\
\hline \multicolumn{14}{|l|}{ Unsaturated } \\
\hline $\mathrm{C}_{16: 1} \omega 7 c$ alcohol & 6.6 & 2.7 & 1.0 & 0.5 & 3.9 & - & 3.6 & 2.2 & 18.9 & 5.5 & 2.4 & 2.8 & - \\
\hline \multicolumn{14}{|l|}{ Branched } \\
\hline iso- $\mathrm{C}_{14: 0}$ & 26.1 & 1.8 & 4.3 & 5.5 & 20.9 & 7.5 & 4.7 & 11.0 & 7.6 & 3.4 & 4.1 & 15.4 & 5.6 \\
\hline iso- $\mathrm{C}_{15: 0}$ & 32.3 & 7.6 & 4.3 & 45.5 & 34.6 & 27.7 & 55.8 & 37.6 & 1.4 & 4.0 & 6.4 & 6.9 & 49.5 \\
\hline anteiso- $\mathrm{C}_{15: 0}$ & 15.2 & 62.7 & 76.8 & 37.7 & 30.8 & 39.6 & 23.5 & 41.1 & 39.8 & 61.8 & 68.4 & 48.6 & 33.3 \\
\hline iso- $\mathrm{C}_{16: 0}$ & 10.0 & 0.6 & 1.6 & 1.1 & 4.4 & - & 3.6 & 2.6 & 7.0 & 1.5 & 2.1 & 7.5 & 4.2 \\
\hline
\end{tabular}

${ }^{\star}$ Data from: $a$, Yu et al. (2008); b, Yoon et al. (2001); c, An et al. (2007).

$\dagger$ Summed feature 4 contains iso- $\mathrm{C}_{17: 1} \mathrm{I}$ and/or anteiso- $\mathrm{C}_{17: 1} \mathrm{~B}$.

approximately $1.0: 1.5: 1.0: 2.0$. Dinitrophenylation revealed that glutamic acid represents the $N$-terminus of the interpeptide bridge. From these data and the appearance of the peptides L-Ala-D-Glu, D-Ala-D-Glu, L-Lys-Gly and L-Lys-DAla in the partial hydrolysates of the peptidoglycan $(4 \mathrm{M}$ $\mathrm{HCl}, 100{ }^{\circ} \mathrm{C}, 0.75 \mathrm{~h}$ ), the peptidoglycan type A4 $\alpha$ L-Lys-GlyD-Glu (Schleifer \& Kandler, 1972) was concluded for both strains $6062^{\mathrm{T}}$ and R-31323.

DNA $\mathrm{G}+\mathrm{C}$ content, determined by HPLC, for strains $6062^{\mathrm{T}}, 4331$ and $\mathrm{R}-31323$ was $42.4,42.4$ and $42.2 \mathrm{~mol} \%$, respectively [for method see (Logan et al., 2000; Mesbah et al., 1989)], and is concordant with the emended description for the genus Sporosarcina (Yoon et al., 2001).

Phylogenetic analysis was performed using near full-length 16S rRNA gene sequences from the six novel Sporosarcina strains deposited and the top 50 BLAST hits returned for type strain $6062^{\mathrm{T}}$ from the EzTaxon (Chun et al., 2007) database. These sequences were aligned using the CLUSTAL $\mathrm{W}$ utility in MEGA 4.0.2 (Tamura et al., 2007) and exported to PhyML 3.0 (Guindon \& Gascuel, 2003). An unrooted maximumlikelihood tree was recreated using the general time reversal model, six substitution rate categories and 5 random starting trees (Guindon \& Gascuel, 2003). Tree reliability was evaluated using approximate likelihood ratio test (aLRT) (Anisimova \& Gascuel, 2006) (Fig. 1). This analysis shows strong support for the novel strains of $S$. newyorkensis sp. nov. residing basally in the clade that harbours S. koreensis, S. luteola, S. thermotolerans, S. saromensis, S. aquimarina and S. ureae.

Characteristics described in the emended description for the genus Sporosarcina (Yoon et al., 2001) that support inclusion of our strains within the genus are: (i) Gram-positive rods, (ii) formation of round endospores, (iii) motile, (iv) facultatively anaerobic, (v) oxidase- and catalase-positive, (vi) hydrolysis of urea but not starch, (vii) CFA composition (Table 2 and species description), (viii) MK-7 as the major menaquinone, (ix) L-lysine as the diamino acid of the peptidoglycan and $(\mathrm{x})$ the DNA $\mathrm{G}+\mathrm{C}$ content. Additional support is provided by the phylogenetic analysis (see above).

The following characteristics support exclusion from the neighbouring genera: (i) the single species of the genus Filibacter is a Gram-negative filamentous rod that shows gliding motility and does not form endospores (Clausen et al., 1985; Maiden \& Jones, 1984); (ii) the two species of the genus Paenisporosarcina are non-motile and have MK-8 as well as MK-7 as a major menaquinone (Krishnamurthi et al., 2009); (iii) the three species of the genus Psychrobacillus have MK- 8 as the major menaquinone, are urease-negative, and the cell wall peptidoglycan is of the A $4 \beta$ type (Krishnamurthi et al., 2010).

Characteristics that aid in distinguishing the novel Sporosarcina strains from other species of the genus Sporosarcina are: (i) for S. soli, Sporosarcina globispora and 


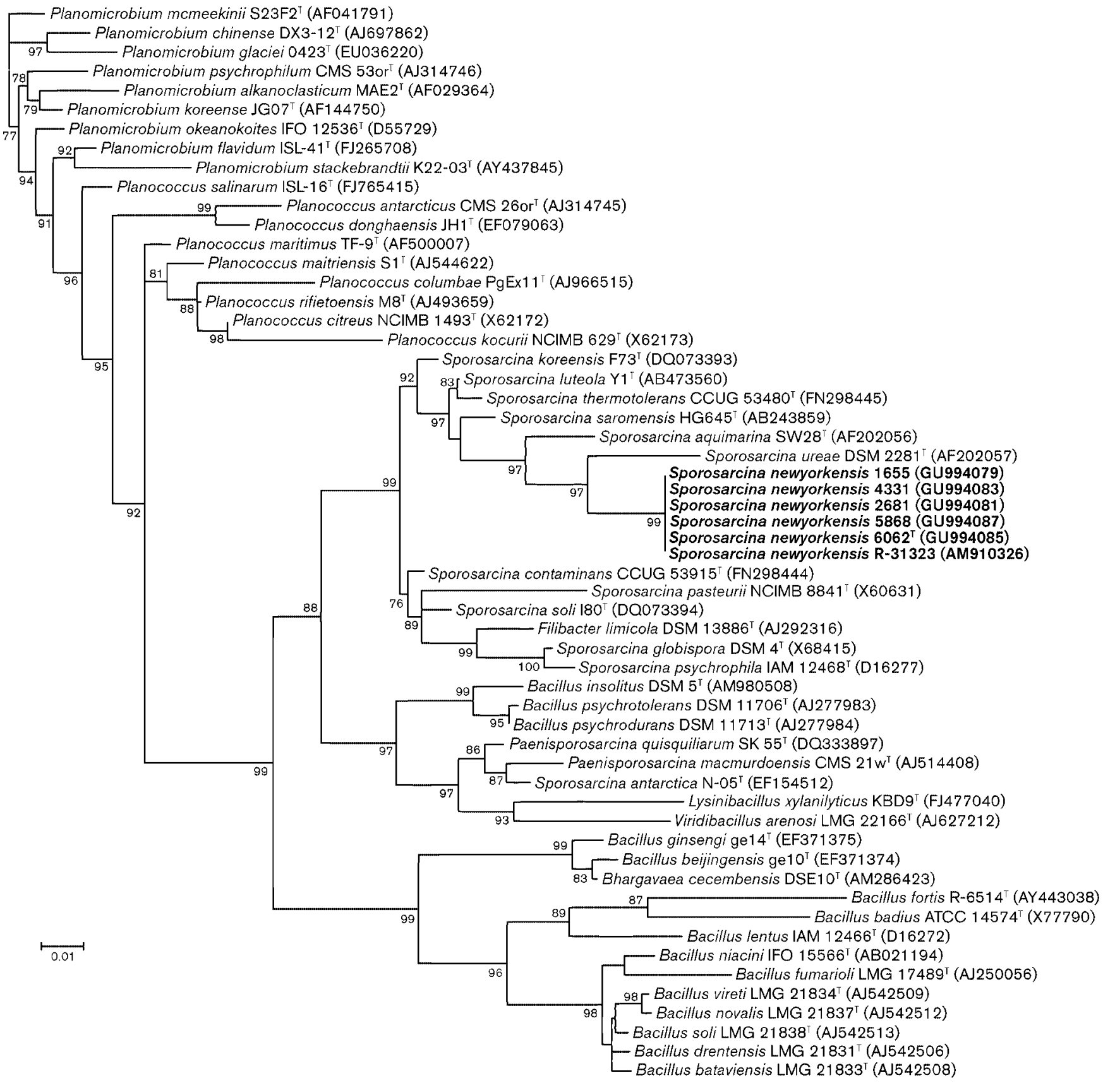

Fig. 1. An unrooted, maximum-likelihood phylogenetic tree, for Sporosarcina newyorkensis sp. nov. and the 50 closest taxa returned from a BLAST search of EzTaxon (see text). Branch probability is indicated at the nodes and determined by aLRT. Probabilities below $50 \%$ are not shown and the branches are collapsed. Bar, expected changes per site.

Sporosarcina psychrophila, the absence of acid production from various carbohydrates in Gordon base medium; (ii) for S. ureae, the presence of DNase activity and rod-shaped cells; (iii) for S. contaminans, S. luteola and Sporosarcina antarctica, the presence of urease activity; (iv) for S. koreensis, S. aquimarina, S. luteola and S. thermotolerans, the absence of lysozyme resistance; (v) for $S$. saromensis, absence of hydrolysis of starch; (vi) other characteristics including the absence of trypsin activity (API ZYM, bioMérieux) and the relative abundance of major CFA (Tables 2 and 3 ). Additionally, strains $6062^{\mathrm{T}}$ and R-31323 share the peptidoglycan structure A4 $\alpha$ L-Lys-Gly-D-Glu with $S$. ureae (Stackebrandt et al., 1987) but differ in this feature from all other type strains of the genus Sporosarcina which do not contain glycine in the interpeptide bridge of the peptidoglycan D-Ala-D-Glu. 
Table 3. Characteristics useful in distinguishing S. newyorkensis sp. nov. from other species of the genus Sporosarcina

Taxa: 1, strain $6062^{\mathrm{T}}$; 2, S. ureae DSM $2281^{\mathrm{T}}$; 3, S. aquimarina DSM $14554^{\mathrm{T}} ; 4$, S. soli DSM $16920^{\mathrm{T}}$; 5, S. koreensis DSM $16921^{\mathrm{T}}$; 6, S. thermotolerans CCUG $53480^{\mathrm{T}} ; 7$, S. contaminans CCUG $53915^{\mathrm{T}} ; 8$, S. luteola DSM $23150^{\mathrm{T}}$; 9, S. saromensis $\mathrm{HG} \mathrm{H}^{\mathrm{T}}$; 10 , S. globispora DSM $4^{\mathrm{T}}$; 11 , S. psychrophila KCTC $3446^{\mathrm{T}}$; 12, S. pasteurii KCTC $3558^{\mathrm{T}}$; 13, S. antarctica N- $05^{\mathrm{T}}$. T, Terminal; ST, subterminal; C, central; R, rod; S, spherical; NA, not available.

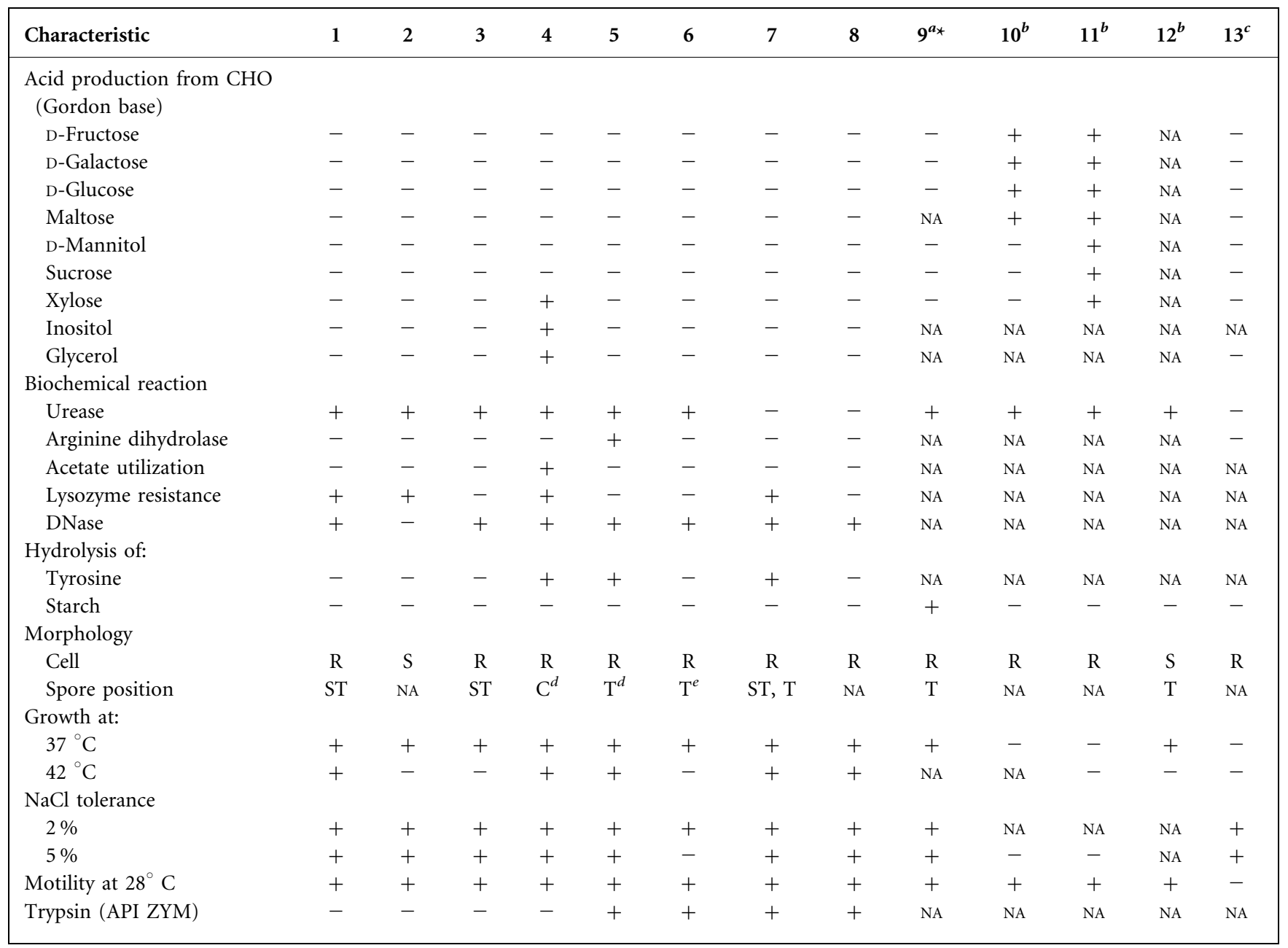

${ }^{\star}$ Data from; a, An et al. (2007); b, Yoon et al. (2001); c, Yu et al. (2008); d, Kwon et al. (2007); e, Kämpfer et al. (2010).

Based on $16 \mathrm{~S}$ and $23 \mathrm{~S}$ rRNA gene sequences, DNA-DNA hybridization, CFA composition, peptidoglycan type, polar lipid content, DNA G+C content and phenotypic and phylogenetic analyses, we propose that the twelve novel strains (Table 1) all represent a single species, Sporosarcina newyorkensis sp. nov.

\section{Description of Sporosarcina newyorkensis sp. nov.}

Sporosarcina newyorkensis (new.york.en'sis. N.L. fem. adj. newyorkensis of or belonging to the state of New York in the USA, where the majority of isolates were obtained).

Cells are Gram-positive rods $(1.5 \times 0.6 \mu \mathrm{m})$, arranged singly or in palisades, are facultative anaerobes, and are motile at $28{ }^{\circ} \mathrm{C}$. Five of the twelve strains from this study display motility at $37^{\circ} \mathrm{C}$, whereas the other strains are non-motile at this temperature (for all variable characters see
Supplementary Table S4). Round to slightly oval subterminal spores form in swollen sporangia. Colonies are 3.1 to $4.1 \mathrm{~mm}$ in diameter after $48 \mathrm{~h}$, moist, grey, circular, raised and have entire margins with no haemolysis at $24 \mathrm{~h}$, but slight beta-haemolysis at $48 \mathrm{~h}$ of incubation $\left(37^{\circ} \mathrm{C}\right.$ in air). A strong odour is present. Growth occurs from 10 to $42{ }^{\circ} \mathrm{C}$ with optimal growth between 22 and $28{ }^{\circ} \mathrm{C}$ determined by turbidity in TSB ( 9 of 12 and 8 of 12 strains can grow at $45{ }^{\circ} \mathrm{C}$ and $55{ }^{\circ} \mathrm{C}$, respectively). The $\mathrm{pH}$ optimum is between $\mathrm{pH} 7.2$ and 9.5 determined by turbidity in TSB adjusted to the appropriate $\mathrm{pH}$. Growth is observed in 2 to $13 \% \mathrm{NaCl}(2$ of 12 and 4 of 12 strains unable to grow above 8 and $10 \%$ $\mathrm{NaCl}$, respectively). Oxidase, catalase, urease and DNase are present and cells are resistant to lysozyme. Cells are negative for hydrolysis of casein, tyrosine, aesculin, adenine, xanthine, hypoxanthine and starch. Cells are negative for the methyl red/Voges-Proskauer tests. Cells are negative for decarboxylation of arginine, lysine and ornithine using 
Moeller's decarboxylase medium and the utilization of acetate. Cells are variable for gelatinase (2 of 12 strains positive), phenylalanine deaminase ( 1 of 12 strains positive), nitrate reduction (7 of 12 strains positive) and utilization of Simmons' citrate (2 of 12 strains positive) (Atlas, 1993; Forbes et al., 1998; Priest et al., 1988). Cells are negative for acid production (Gordon sugar base containing $10 \%$ carbohydrate) from adonitol, L-arabinose, cellobiose, Dfructose, D-galactose, D-glucose, glycerol, inositol, lactose, maltose, D-mannitol, D-mannose, melibiose, raffinose, Drhamnose, D-salicin, D-sorbitol, sucrose, trehalose and Dxylose (Gordon et al., 1973). API ZYM reactions were variable for esterase (C4) (3 of 12 strains positive), esterase lipase (C8) (8 of 12 strains positive), $\alpha$-chymotrypsin ( 8 of 12 strains positive), leucine arylamidase (2 of 12 strains positive), cystine arylamidase ( 1 of 12 strains positive), naphthol-AS-BI-phosphohydrolase (1 of 12 strains positive) alkaline phosphatase ( 1 of 12 strains positive), $\alpha$-galactosidase ( 1 of 12 strains positive) and $\beta$-glucuronidase ( 2 of 12 strains positive). Negative for valine arylamidase, acid phosphatase, lipase (C14), trypsin, $\beta$-galactosidase, $\alpha$ glucosidase, $\beta$-glucosidase, $N$-acetyl- $\beta$-glucosaminidase, $\alpha$ mannosidase and $\alpha$-fucosidase. No reaction to the carbohydrates in the API $50 \mathrm{CH}$ test strip. The predominant fatty acids are iso- $\mathrm{C}_{14: 0}$, iso- $\mathrm{C}_{15: 0}$ and anteiso- $\mathrm{C}_{15: 0}$. The peptidoglycan type is A4 $\alpha$ L-Lys-Gly-D-Glu. DNA G + C content is $42.4 \mathrm{~mol} \%$. The major menaquinone is MK-7.

The type strain, $6062^{\mathrm{T}}\left(=\right.$ DSM $23544^{\mathrm{T}}=$ CCUG $59649^{\mathrm{T}}$ $=\mathrm{LMG} 26022^{\mathrm{T}}$ ) was isolated from a patient's blood in New York State, USA.

\section{Acknowledgements}

We thank the Wadsworth Center Applied Genomic Technologies Core for sequencing, the Wadsworth Center Orphan Bacterium Laboratory, the Wadsworth Biodefence Laboratory and the Institute for Agricultural and Fisheries Research for the S. newyorkensis strains, Anika Wasner (DSMZ), Leah Nazarian (WC) and Amy Saylors (WC) for assistance, Donna Kohlerschmidt (WC) for helpful discussions, and Dr Andrea Habura (WC) for assistance with the phylogenetic analysis.

\section{References}

Altschul, S. F., Madden, T. L., Schäffer, A. A., Zhang, J., Zhang, Z., Miller, W. \& Lipman, D. J. (1997). Gapped BLAST and PSI-BLAST: a new generation of protein database search programs. Nucleic Acids Res 25, 3389-3402.

An, S. Y., Haga, T., Kasai, H., Goto, K. \& Yokota, A. (2007). Sporosarcina saromensis sp. nov., an aerobic endospore-forming bacterium. Int J Syst Evol Microbiol 57, 1868-1871.

Anisimova, M. \& Gascuel, O. (2006). Approximate likelihood-ratio test for branches: a fast, accurate, and powerful alternative. Syst Biol 55, 539-552.

Atlas, R. M. (1993). Handbook of Microbiological Media. Edited by L. C. Parks. Boca Raton, FL: CRC Press.

Cashion, P., Holder-Franklin, M. A., McCully, J. \& Franklin, M. (1977). A rapid method for the base ratio determination of bacterial DNA. Anal Biochem 81, 461-466.
Chun, J., Lee, J. H., Jung, Y., Kim, M., Kim, S., Kim, B. K. \& Lim, Y. W. (2007). EzTaxon: a web-based tool for the identification of prokaryotes based on $16 \mathrm{~S}$ ribosomal RNA gene sequences. Int J Syst Evol Microbiol 57, 2259-2261.

Claus, D. \& Fahmy, F. (1986). Genus Sporosarcina Kluyver and van Niel 1936, 401 ${ }^{\mathrm{AL}}$. In Bergey's Manual of Systematic Bacteriology, vol. 2, pp. 1202-1206. Edited by P. H. A. Sneath, N. S. Mair, M. E. Sharpe \& J. G. Holt. Baltimore: Williams \& Wilkins.

Clausen, V., Jones, J. G. \& Stackebrandt, E. (1985). 16S ribosomal RNA analysis of Filibacter limicola indicates a close relationship to the genus Bacillus. J Gen Microbiol 131, 2659-2663.

Coorevits, A., De Jonghe, V., Vandroemme, J., Reekmans, R., Heyrman, J., Messens, W., De Vos, P. \& Heyndrickx, M. (2008). Comparative analysis of the diversity of aerobic spore-forming bacteria in raw milk from organic and conventional dairy farms. Syst Appl Microbiol 31, 126-140.

De Ley, J., Cattoir, H. \& Reynaerts, A. (1970). The quantitative measurement of DNA hybridization from renaturation rates. Eur $J$ Biochem 12, 133-142.

Ezaki, T., Hashimoto, Y. \& Yabuuchi, E. (1989). Fluorometric deoxyribonucleic acid-deoxyribonucleic acid hybridization in microdilution wells as an alternative to membrane filter hybridization in which radioisotopes are used to determine genetic relatedness among bacterial strains. Int J Syst Bacteriol 39, 224-229.

Forbes, B. A., Sahm, D. F. \& Weissfeld, A. S. (1998). Overview of bacterial identification methods and strategies. In Bailey and Scott's Diagnostic Microbiology, 10th edn, pp. 424-446. Edited by J. Roche. St. Louis, MO: Mosby.

Gordon, R. E., Haynes, W. C. \& Pang, C. H.-N. (1973). Media and methods. In The Genus Bacillus, US Department of Agriculture Handbook no. 427, pp. 2-14. Washington, DC: US. Government Printing Office.

Groth, I., Schumann, P., Weiss, N., Martin, K. \& Rainey, F. A. (1996). Agrococcus jenensis gen. nov., sp. nov., a new genus of actinomycetes with diaminobutyric acid in the cell wall. Int J Syst Bacteriol 46, 234239.

Guindon, S. \& Gascuel, O. (2003). A simple, fast, and accurate algorithm to estimate large phylogenies by maximum likelihood. Syst Biol 52, 696-704.

Huß, V. A. R., Festl, H. \& Schleifer, K. H. (1983). Studies on the spectrophotometric determination of DNA hybridization from renaturation rates. Syst Appl Microbiol 4, 184-192.

Kämpfer, P., Falsen, E., Lodders, N. \& Schumann, P. (2010). Sporosarcina contaminans sp. nov. and Sporosarcina thermotolerans sp. nov., two endospore-forming species. Int J Syst Evol Microbiol 60, 1353-1357.

Krishnamurthi, S., Bhattacharya, A., Mayilraj, S., Saha, P., Schumann, P. \& Chakrabarti, T. (2009). Description of Paenisporosarcina quisquiliarum gen. nov., sp. nov., and reclassification of Sporosarcina macmurdoensis Reddy et al. 2003 as Paenisporosarcina macmurdoensis comb. nov. Int J Syst Evol Microbiol 59, 1364-1370.

Krishnamurthi, S., Ruckmani, A., Pukall, R. \& Chakrabarti, T. (2010). Psychrobacillus gen. nov. and proposal for reclassification of Bacillus insolitus Larkin \& Stokes, 1967, B. psychrotolerans Abd-El Rahman et al., 2002 and B. psychrodurans Abd-El Rahman et al., 2002 as Psychrobacillus insolitus comb. nov., Psychrobacillus psychrotolerans comb. nov. and Psychrobacillus psychrodurans comb. nov. Syst Appl Microbiol 33, 367-373.

Kwon, S. W., Kim, B. Y., Song, J., Weon, H. Y., Schumann, P., Tindall, B. J., Stackebrandt, E. \& Fritze, D. (2007). Sporosarcina koreensis sp. nov. and Sporosarcina soli sp. nov., isolated from soil in Korea. Int J Syst Evol Microbiol 57, 1694-1698. 
Logan, N. A., Lebbe, L., Hoste, B., Goris, J., Forsyth, G., Heyndrickx, M., Murray, B. L., Syme, N., Wynn-Williams, D. D. \& De Vos, P. (2000). Aerobic endospore-forming bacteria from geothermal environments in northern Victoria Land, Antarctica, and Candlemas Island, South Sandwich archipelago, with the proposal of Bacillus fumarioli sp. nov. Int J Syst Evol Microbiol 50, 1741-1753.

MacKenzie, S. L. (1987). Gas chromatographic analysis of amino acids as the $\mathrm{N}$-heptafluorobutyryl isobutyl esters. J Assoc Off Anal Chem 70, 151-160.

Maiden, M. F. J. \& Jones, J. G. (1984). A new filamentous gliding bacterium, Filibacter limicola gen. nov. sp. nov., from lake sediment. J Gen Microbiol 130, 2943-2959.

Mesbah, M., Premachandran, U. \& Whitman, W. B. (1989). Precise measurement of the $\mathrm{G}+\mathrm{C}$ content of deoxyribonucleic acid by highperformance liquid chromatography. Int J Syst Bacteriol 39, 159-167.

Priest, F. G., Goodfellow, M. \& Todd, C. (1988). A numerical classification of the genus Bacillus. J Gen Microbiol 134, 1847-1882.

Schleifer, K. H. (1985). Analysis of the chemical composition and primary structure of murein. Methods Microbiol 18, 123-156.

Schleifer, K. H. \& Kandler, O. (1972). Peptidoglycan types of bacterial cell walls and their taxonomic implications. Bacteriol Rev 36, 407-477.

Stackebrandt, E., Ludwig, W., Weizenegger, M., Dorn, S., McGill, T. J., Fox, G. E., Woese, C. R., Schubert, W. \& Schleifer, K. H. (1987). Comparative $16 \mathrm{~S}$ rRNA oligonucleotide analyses and murein types of round-spore-forming bacilli and non-spore-forming relatives. J Gen Microbiol 133, 2523-2529.

Tamura, K., Dudley, J., Nei, M. \& Kumar, S. (2007). MEGA4: molecular evolutionary genetics analysis (MEGA) software version 4.0. Mol Biol Evol 24, 1596-1599.

Tindall, B. J. (1990a). A comparative study of the lipid composition of Halobacterium saccharovorum from various sources. Syst Appl Microbiol 13, 128-130.

Tindall, B. J. (1990b). Lipid composition of Halobacterium lacusprofundi. FEMS Microbiol Lett 66, 199-202.
Tindall, B. J., Rosselló-Móra, R., Busse, H.-J., Ludwig, W. \& Kämpfer, P. (2010). Notes on the characterization of prokaryote strains for taxonomic purposes. Int J Syst Evol Microbiol 60, 249-266.

Tominaga, T., An, S. Y., Oyaizu, H. \& Yokota, A. (2009). Sporosarcina luteola sp. nov. isolated from soy sauce production equipment in Japan. J Gen Appl Microbiol 55, 217-223.

Wayne, L. G., Brenner, D. J., Colwell, R. R., Grimont, P. A. D., Kandler, O., Krichevsky, M. I., Moore, L. H., Moore, W. E. C., Murray, R. G. E. \& other authors (1987). Report of the ad hoc committee on reconciliation of approaches to bacterial systematics. Int J Syst Bacteriol 37, 463-464.

Willems, A., Doignon-Bourcier, F., Goris, J., Coopman, R., de Lajudie, P., De Vos, P. \& Gillis, M. (2001). DNA-DNA hybridization study of Bradyrhizobium strains. Int J Syst Evol Microbiol 51, 13151322.

Wolfgang, W. J., Carpenter, A. N., Cole, J. A., Gronow, S., Habura, A., Jose, S., Nazarian, E. J., Kohlerschmidt, D. J., Limberger, R. \& other authors (2011). Neisseria wadsworthii sp. nov. and Neisseria shayeganii sp. nov. isolated from clinical specimens. Int J Syst Evol Microbiol 61, 91-98.

Yoon, J. H., Lee, K. C., Weiss, N., Kho, Y. H., Kang, K. H. \& Park, Y. H. (2001). Sporosarcina aquimarina sp. nov., a bacterium isolated from seawater in Korea, and transfer of Bacillus globisporus (Larkin and Stokes 1967), Bacillus psychrophilus (Nakamura 1984) and Bacillus pasteurii (Chester 1898) to the genus Sporosarcina as Sporosarcina globispora comb. nov., Sporosarcina psychrophila comb. nov. and Sporosarcina pasteurii comb. nov., and emended description of the genus Sporosarcina. Int J Syst Evol Microbiol 51, 1079-1086.

Yu, Y., Xin, Y. H., Liu, H. C., Chen, B., Sheng, J., Chi, Z. M., Zhou, P. J. \& Zhang, D. C. (2008). Sporosarcina antarctica sp. nov., a psychrophilic bacterium isolated from the Antarctic. Int J Syst Evol Microbiol 58, 2114-2117.

Zhang, Z., Schwartz, S., Wagner, L. \& Miller, W. (2000). A greedy algorithm for aligning DNA sequences. J Comput Biol 7, 203-214. 